\title{
Linguistic Aspects of taxtaxa, a Sociolinguistic Perspective
}

\author{
Ahmad Khalaf Sakarna ${ }^{1}$ \\ ${ }^{1}$ Department of English Language \& Literature, Mu'tah University, Jordan \\ Correspondence: Ahmad Khalaf Sakarna, Department of English Language \& Literature, Mu'tah University, P. \\ O. BOX (7), Mu’tah, Al-Karak, Jordan. Tel: 962-77-771-7478. E-mail: asakarna@hotmail.com
}

Received: October 7, 2012 Accepted: November 5, 2012 Online Published: December 31, 2012

doi:10.5539/ass.v9n1p218

URL: http://dx.doi.org/10.5539/ass.v9n1p218

\begin{abstract}
One of the most interesting phenomena of using language in an administrative setting in Jordan is commonly referred to as țaxtaxa 'shooting'. That is, to use a specific version of Arabic to fight, argue against, or weaken the status of a person who is leading an administrative position or who has an administrative status. Linguistic investigation and complete understanding of this phenomenon, as far as I know, has not been studied yet.(Note 1) The present research attempts to explore the linguistic components associated with the use of language in an administrative setting. It shows that the use of language in such a setting triggers the application of specific linguistic structures that contain particular statements, expressions, terms, and idioms. It also views the use of language in an administrative setting as an art of fighting with words, as the user tends to apply taxtaxa aggressively to achieve certain objects. The paper discusses and provides evidence for the different elements of 'shooting' which include its definition, labels, levels, types, users, reasons, objects, times, reaction to, and effects, respectively.
\end{abstract}

Keywords: Arabic linguistics, Arabic sociolinguistics, Arabic pragmatics, administrative linguistics, applied linguistics

\section{Introduction}

Current linguistic trends have presented two opposing views about the nature of using language as a tool of communication in a broad sense. One view suggests a peaceful use that aims at facilitating interaction between members of a linguistic community (Suleiman 1995, Coulmas1998, Searle 2000, Romaine 2000, Owens 2001, Boxer 2002, Downes 2005, Owens 2006, Coulmas 2006, and Bassiouney 2009), the other claims that language is a tool that utilizes a non-peaceful communication that initiates or copes with "conflicts." (Eadie and Nelson 2000 , Rouchdy, 2003, Thomas et al 2003, and Suleiman. 2004). The complex and sophisticated nature of language use, however, justifies the realistic and reasonable vision of these conflicting views. Narrowing the scope of the second vision to include specific setting would help understand how language use functions in "conflicts", which "are dependent on how the speakers interpret the facts of their situation" (Suleiman 2004: 55), and provide further evidence to such view. As far as I know, using language the non-peaceful way in an administrative milieu is not investigated yet, an issue that raises a high need to fill in this gap in the current linguistic trends. (Note 2)

\section{What is taxtaxa?}

The literal translation for the term țaxtaxa is 'shooting'. It is derived from the root țaxx, which means 'shoot'. The process of 'shooting' can be defined as talking about or against someone to someone else. As shown in figure 1 , below, person number 1 is talking to person 2 about 3 . 


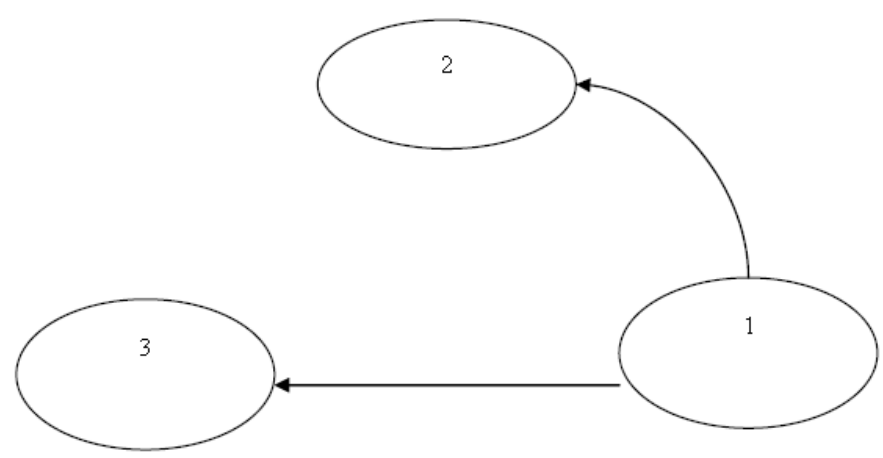

Figure 1. Person number 1 is talking to person 2 about 3.

The process of taxtaxa is negatively looked at by people, because of its negative and non peaceful effect on the targeted person. (Note 3) It is derived from a root that denotes a sense of 'fighting', 'participating in a battle', or 'joining a war' to express its impact. It is a starting point or a trigger of what is known as "a war of words" (Suleiman, 2004), a case where the insight of Owens (2001, 2006) is neither followed nor adopted, where sociolinguistics interaction does not proceed in a peaceful way and takes a form of a fight, a battle, or a war in which specific expressions are used and causalities, loss, or destructions are expected.

The process of 'shooting' itself is also described by some expressions:
(1) hazz danab 'tail shaking'
masifi $\breve{g} \bar{u} x$ 'clothes washing'
fǐ̌a 'shooting'
isfin 'shooting'
gașș 'telling untrue stories'

$$
\begin{aligned}
& \text { tašlīx 'shooting' } \\
& \text { 'ariț 'lying' }
\end{aligned}
$$

\section{Labels}

The person who practices taxtaxa is usually referred to by the following local terms:
(2) bitnațt 'jumper'
laggāg 'big mouth'
xrity 'liar'
hazzāz đanab 'tail shaker' massīf ğ gūx 'clothes cleaner' 'arịt'liar'
gașșiș (untrue) story teller'

A skillful țaxxīx 'shooter', who practices țaxtaxa regularly and successfully, is usually addressed by certain labels or nicknames that donate a negative or positive social image. In both cases, such labels represent an underlying negative connotation.

\subsection{Negative Labels}

(3) mutasalliq 'climber'

xibiO 'mean'

mā bin 'a ta 'ein 'never respected'

3.2 Positive Labels

(4) $\mathrm{mad}^{\prime}$ 'um 'supported' mușaddaq 'truthful'

kilimtuh mā bitsīr Onīn 'his word never gets two'

Although these terms sound positive, but they are implicitly negative.

\section{Levels of taxtaxa}

There are two levels of shooting depending on who practices it and who the target is.

\subsection{Low}

This type goes in two dimensions. First, it could be practiced between employees, who, for certain reasons, don't get along with their boss. As show in Figure 2, employee A, B, and C are talking against their boss. 


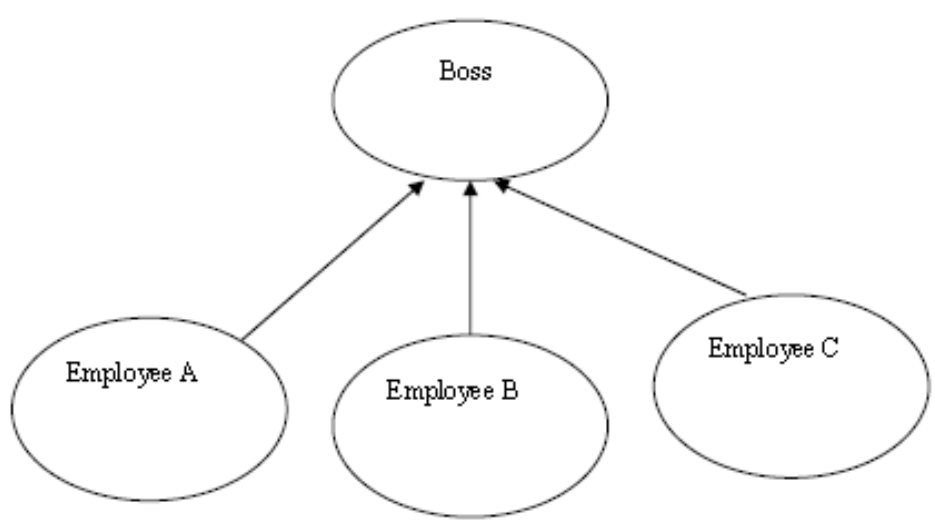

Figure 2. Employee A, B, and C are talking against their boss

Shooters usually express their disapproval of their boss by using certain strategies:

1) Imitating his way of speaking.

2) Repeating the same word or sentence said by him.

3) Commenting on him ironically.

4) Making jokes about him.

5) Looking down to what he says.

Second, it might be used by employees themselves against one of their peers. An employee may express his disapproval of a peer by talking against this peer to the boss using the same strategies mentioned earlier, as shown in Figure 3 where employee $\mathrm{A}$ is talking against employee $\mathrm{B}$ to the boss.

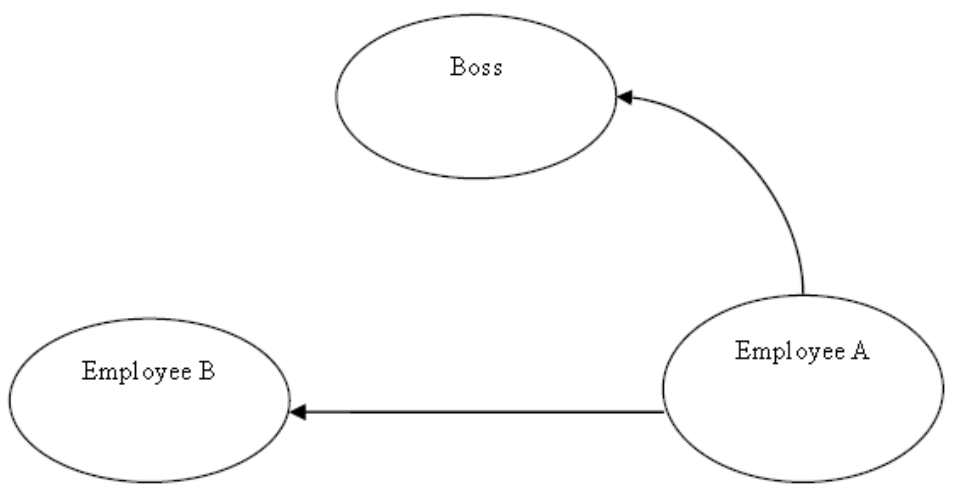

Figure 3. Employee A is talking against employee B to the boss

\subsection{High}

This type takes place when an employee meets a higher boss to complain about his immediate boss. It also happens when a boss meets a higher boss to complain either about a competing person or an employee. A shooter in these situations follows the strategy of pointing out the weakness of the target. The three cases are illustrated in Figure 4, where (4.A) an employee is talking against his immediate boss to a higher boss, in (4.B) a boss is arguing against a competing person to a higher boss, and in (4.C) a boss is complaining about an employee to a higher boss. (The curved line represents the destination to which taxtaxa should arrive, the straight line represents the targeted person): 

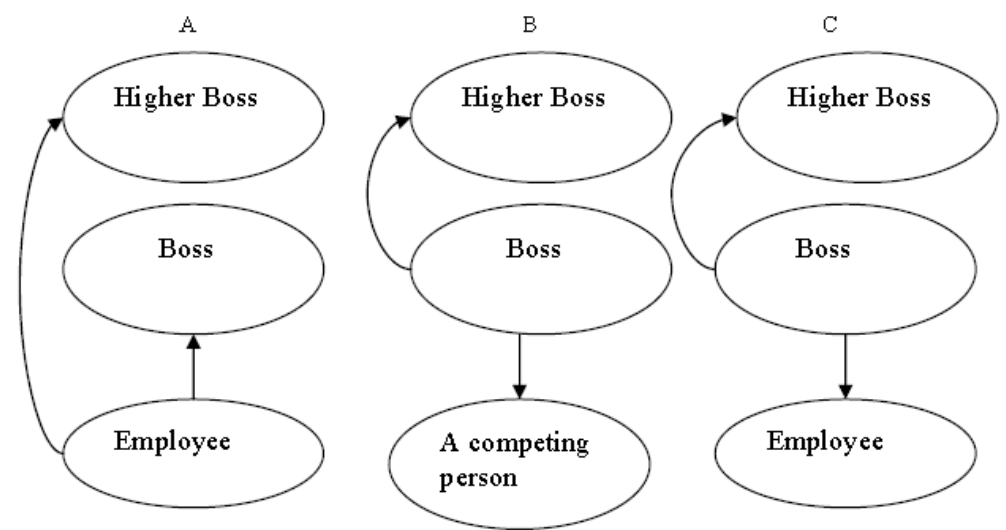

Figure 4. (A) An employee is talking against his immediate boss to a higher boss. (B) A boss is arguing against a competing person to a higher boss. (C) A boss is complaining about an employee to a higher boss.

\section{Types of taxtaxa}

There are two types of taxtaxa; overt and covert. The former entails attacking the targeted person publicly on face to point out his problems and mistakes, while the latter is made indoors behind the target and normally addresses the boss of the target.

\subsection{Overt}

Examples of overt țaxtaxa include the following statements used by a shooter in which the complement is always a negative statement:

(5) șafiīi gult ...

'is it true that you said....'

bigūlu 'annak ...

'they say about you....'

leiš 'imilit ...

'why did you do.....'

fassirly leiš $\quad \ldots$

'explain to me why....'

šu alg̀āya min ...

'what is the object of ....'

$\check{s} \bar{u}$ răyak bikalam flān ... ' 'what do you think of the opinion of people about.....'

The audience who witnesses this type of 'shooting' usually labels it with negative terms like wağhana 'keeping face', šakwana 'complaining', and $m z$ āwada 'claiming loyalty'.

\subsection{Covert}

This type is considered more effective and destructive since the targeted person is not given the chance to defend his view. It is referred to as fasfasa 'gossiping', dasdasa 'insertion', zarwaga 'zigzaging', națnața 'jumping', or țahina 'grounding'.

The shooter usually uses the following expressions:

(6) simi 'it ....

bigūlu ...

la $\operatorname{tğ} \bar{\imath} b$ sìra ....

beiny wa beinak ...

lulā ma'aztik 'indy, mā gultlak ... mišānak lāzim ti 'raf innuh...

lafiada ġeirak mā fiakeit...

bafiki 'ašān almașlafia al 'àma....

\author{
'I heard that...' \\ 'people say that...' \\ 'don't mention that....' \\ 'between you and me.....'
}

'because you dear, I've told you...'

'for your sake, you should know....'

'I would not mention that to someone else...'

'I am talking because of the public interest'

\section{Users of taxtaxa}

A normal employee may turn into a shooter who finds it a need to verbally attack his boss in the following situations. First, when the boss does not respond to the shooter's personal needs:

(7) faššalny 'he disappointed me' nafaxit bgirba maxzūga 'I blew air in a torn bag'

'ana bwād wa hü bwād 'I am in a valley and he is in a different valley' 
mas'ūl gaby 'a stupid boss'

Second, when the boss applies regulations strictly so that the shooter objects are not met:

(8) ğilif 'stubborn' mā buxiđwalā ba'ty 'he never gives or takes'

'abù atta 'lìmāt 'father of regulations'

'ala doary șār nizāmy 'he applies the rules on me'

Third, when the boss is not fair:

(9) 'ibin fiarām 'sun of a gun' zālim 'unjust'

mal 'ūn wāldein 'parents' disobedient'

Fourth, when the boss is not flexible:

(10) loafi 'a board' xašaba 'a wood' fieiț'a wall'

Fifth, when the boss practices bad or corrupted administration:

(11) fāšil 'a failure' șāgiț 'unsuccessful' fārig 'empty'

Meanwhile, a shooter may practice țattaxa against a peer when reasons, as will be discussed below, are available.

\section{Reasons for taxtaxa}

The process of 'shooting' is triggered by one of the following factors, depending on the targeted person who might be a boss or a peer.

\subsection{Shooting against a Boss}

\subsubsection{To Take Revenge from the Boss}

The prefix $b a$ - in the following examples represents future threat.

(12) bašiffuh 'I will hit him'

ba 'alğuh 'I will cure him'

badāwīh 'I will treat him'

ba 'arfuh fiağmuh 'I will let him know his worth'

7.1.2 To Announce Boss Mistakes

(13) lakšif wrāguh 'I will reveal his papers'

kalamuh miš safiitti 'his speech is wrong'

šugluh miš șafi 'his work is wrong'

7.1.3 To Reveal Boss Violations

(14) xālaf atta 'līmāt 'he violated the regulations'

miš mazbūt 'his is not on the right track'

bitāfiyal 'alqānūn 'he is fooling the law'

idāry fāšil 'administratively corrupt'

walla $m \bar{a}$ 'afawitha iluh 'I swear not to forgive him'

'àrif maxābīh 'I know his secrets'

\subsubsection{To Impose Boss Response}

(15) min huwwa 'who is he!' mīn warāh 'who is supporting him!'

al'ayām beinna 'days between us'

7.1.5 Jealousy from the Boss

(16) 'ala eiš 'for what!' min huwwa 'who is he!' $\check{s} \bar{u}$ biswa 'what is his worth' bafzafiu 'I will scandalize him'

baballig 'annuh 'I will inform about him'

bawarğih 'I will show him' kulluh 'xtā' 'his is full of mistakes'

galtān 'he is wrong'

'abu algaltāt ' father of mistakes' $\check{s} \bar{u}$ makanuh 'what is his position!'

$\check{s} \bar{u}$ hadafuh 'what is his goal!'

$\check{s} \bar{u} m u$ 'ahaluh 'what is his qualification!' miš $m$ 'abiyy 'einn $\bar{\imath}$ 'he is not filling my eyes' hãđā illì țili ' minnuh 'is this all what he got!' 


\subsubsection{To Preserve Peers Support}

This is made to gain a group support against the targeted person:

(17) biddu ydammirna 'he wants to destroy us'

biddu yifibițna 'he wants to make us upset'

biddu yxarrib byūtna 'he wants to destroy our houses'

biddu yifirigna 'he wants to burn us'

mā bixaf Allah 'he does not fear God'

$m \bar{a}$ bifiib fiada 'he does not like anybody'

miš šăyifna bi 'yūnuh 'he does not see us with his eyes'

miš fiāsib fisābna 'he does not count us'

7.1.7 To Spread Rumors about the Boss

(18) fialafüly innuh... ' they swore to me that...'

gālüly innuh... 'they told me that....'

simi 'it innuh... 'I heard that.....'

ğāny xabar innuh... 'I got the news that.....'

mit'akkid innuh... 'I am sure that......'

rāfi tšúfu innuh... 'you will see that.....'

7.2 Shooting against a Peer

\subsubsection{Personal Fights or Clashes}

(19) bawarğìh 'I will show him'

barabbīh 'I will raise him'

badamruh 'I will destroy him'

'na warāh wazzaman țawìl 'I am behind him all the way'

7.2.2 Personal Hatred or Jealousy

This surfaces when the 'shooter' asks others not to interact with the targeted person:

(20) dīr bālak minnuh 'be careful from him' lā tiӨiq fìh 'don't trust him'

xarrāb byūt 'he's houses' destroyer' miš sahil 'he is not easy'

$x a b i \theta$ 'he is mean'

bitxalah 'annak 'he will leave you'

$m \bar{a}$ 'induh walā' 'he is not loyal' bifiki bgafäk 'he talks behind your back'

7.2.3 To Defend a Mistake

A shooter may appeal to țaxtaxa to defend a mistake that he made to avoid peers' criticism:

(21) flān mā bifham 'that person does not understand'

bitdaxxal 'he interferes in my business'

bixfi alfiagāy'ig 'he hides the truth'

kađđāa $b$ 'he is a liar'

maškalğy 'he is a trouble shooter'

7.2.4 To Hide the Truth

Criticizing others is another policy to hide a truth that the shooter knows:

(22) flān kađđāa 'that guy is a liar' bikub šarruh 'he is pouring his bad deeds on us'

birmi mașāybuh 'he is throwing his problems on us'

bifayyiš fina 'he is shooting us'

7.2.5 To Practice Power

Shooting on others can also be used to practice power over peers:

(23) ți 'ūni 'obey me'

isma 'u mini 'listen to me' 
ruddu 'alayya 'respond to me' sawwu illī bafikīh 'do what I say'

\section{Objects of taxtaxa}

A shooter struggles to achieve the following objectives:

\subsection{To Gain the Trust of a Higher Boss}

This entails talking to a higher boss against an immediate one.

(24) mā bifham 'he never understands' qarāruh galat' 'his decision is wrong'

lāzim yitgayyar 'he should be changed' $\quad m \bar{a}$ bi 'rif' he never knows'

\subsection{To Achieve Boss Satisfaction}

This requires spying on other peers and reporting their deeds to the boss

(25) biddu ysawwi kađa 'he will do .....'

fiakāli kađa 'he told me ....'

\subsection{To Get Social Status}

A shooter may compete his target as a way to get public reputation by talking against his target openly to take his position. The objects of the shooter in targeting a position can be understood from the following:

(26) wallah mawqi ' fiassās 'I swear it is a sensitive position'

wağāha '(this position) has a high value'

kulluh ma 'ârif '(this position) is full of relations'

mā fih miOluh 'no place like (this position)'

kulluh da 'im '(this position) is full of support'

8.4 To Gain Financial Status

(27) wallah mawqi' fìh 'alāwah

'I swear this position has an allowance'

wallah mawqi' fih xadam

'I swear this position has servants'

wallah mawqi' fih 'sayyārah

'I swear this position has a (free) car'

wallah mawqi' fì telefon

'I swear this position has a (free) phone'

wallah mawqi' fìh mașāry

'I swear this position has (good) money'

8.5 To Be Powerful

(28) halmanșib biftafi kul al'bwāb 'this position opens all the door'

mā fiada bigullak wein rāyitfi 'nobody asks you where are you going'

mā fiada balšān fìk 'nobody questions you'

inta sayyid nafsak 'you are the lord of yourself'

8.6 To Avoid Being a Follower

(29) lā sā'il wala mas'ūl 'no body supervises you'

'amry bīdy

'my decision is in my hand'

dawamy 'ala keify

'I work when I want'

basawy illi bidi yāh

'I do what I want'

mà fiada mfiāsibny

'nobody investigates my work'

8.7 To Hunt a Chair

(30) miš 'afiag minni 'I have more right in this position than him' 'akal fiaggy 'he took my right' 
$m \bar{a}$ 'induh mu'ahalāti 'he does not have my qualifications'

8.8 To Weaken the Status of the Chairman

(31) mā bifham 'he does not understand' $m \bar{a} \quad$ bidāwim 'he does not show up at work' $k \Theta$ ir fiaky 'he speaks a lot' šugluh galaț 'his work is wrong' $m \bar{a}$ bitābi ' he does not follow up' miš daqīq 'he is not accurate'

8.9 To Prove Presence

This happens when arguing against a peer.

(32) badaggig warāh 'I always check his work' nabbahtu 'akӨar min marrah 'I warned him several times' nașafituh 'I advised him' law lāy kān.... 'without me it would not be so' štagalt 'annuh 'I did his work'

\subsection{To Get Personal Needs}

This occurs when talking with a new boss against an old one.

(33) 'adurak șilfiat al'umūr 'you fixed the problems'

'illi gablak xarrabha 'the old boss made problems'

gablak räfi fiagna 'we lost our rights before you'

'adur flān nzalamna 'we were treated unfairly by the old boss'

hassa ' nizman fiagna 'now we guarantee our rights'

8.11 To Destroy the Boss Social Image

(34) mutakabbir 'arrogant' muta 'ağrif 'proud'

bațuh 'ğrab 'his tummy is dirty'

šugul 'azāyim 'he seeks invitations'

ği 'ân 'he is hungry' raxị̣ 'he is cheap'

$m \bar{a}$ 'induh karāmah 'he has no dignity' šâyif fiālluh 'overconfident' hamağy 'barbarian'

bteiny 'he likes his tummy' sarrāg 'he is a thief' ganāṣ furaṣ 'chances hunter'

\subsection{To Achieve Success}

This happens when looking down to the achievements of the targeted person to make people just remember the achievements of the shooter:

(35) miš hal'injāz

'ay wäfiad bi 'malha

mā sāwa ǐsy k $\mathrm{i} \bar{r} r$

hāđa wā̆ğbuh

miš hal'amal almumayyaz

iš̄ 'ādy ğiddan

lula aldaz mā bisawīha 'this achievement is nothing'

'anyone can do that'

'he does not do a big thing'

'this is his job'

'his work is not distinguished'

'this is very normal'

'he cannot do it without others support'

8.13 To Gain Credit for Others Works

A shooter may struggle to maintain a positive administrative image in front of his boss by repeating certain expressions to point out his important role in achieving a particular task, even if someone else has done it:

(36) 'ana 'illi 'milit heik miš huwwa 'I did this not him'

law lāy mā șārat 'it would not happen without me'

'ana šag̀gāl 'aleiha 'I am working on it'

duxut lamma sawweitha 'I worked hard to do it'

'axđat min wagtei $k \Theta \bar{i} r$ 'it took a lot of my time' 
ta 'abatnī $k \Theta \bar{i} r \quad$ 'it exhausted me a lot'

galabt 'aleiha addinya 'I bothered the world to make it'

jannanthum fiatta raddu 'alayya 'I bothered them a lot to reply to me'

8.14 To Mislead the Boss

Misleading the boss, from a shooter perspective, will provide the chance to achieve the desired goals. This involves a continuous complaint about the target:

(37) mas'ūlìtu huwwa 'it his responsibility'

fiāsbu huwwa 'you should question him'

lā trud 'alleih 'don't respond to him'

$x a r r a b$ aššugiul 'he destroyed the work'

8.15 To Trick a Peer

A shooter may talk against a peer to the boss, but when meeting this peer he claims the opposite.
(38) dāfa 'it 'annak
'I defended you'
latțaftilak alğaw
'I cheered it up for you'
gultuluh ysā' dak
'I told him to help you'
đakartak bilxeir
'I mentioned all the good things about you'
minni kul adda'im
'I gave you all my support'

\section{Times of taxtaxa}

The times in which țaxtaxa occurs rely on the following situations.

\subsection{Meeting the Immediate Boss}

In this case, the target is a peer:
(39) $m \bar{a}$ biğğāwab
'he never responds'
xallișna minnuh 'for our sake get rid of him'
xarrab šugulna 'he destroyed our work'
9.2 Meeting the Higher Boss

The target in this case is the immediate boss.

(40) huwwa mudīr willa muwazzaf ' is he a manager or an employee?'

$m \bar{a}$ 'indu xibra 'he lacks experience'

axtā'uh rafi tbayyin 'his mistakes will show'

\subsection{Meeting Peers}

In this case the target is the immediate boss or an other peer.
(41) là trud 'alleih 'don't respond to him'
mà binxadim 'he does not deserve our effort'
$m \bar{a}$ bigaddir he does not appreciate others'

\author{
ifiligluh 'ignore him' \\ izbiluh 'treat him like trash' \\ țanšuh 'quit dealing with him’
}

\section{Reaction to taxtaxa}

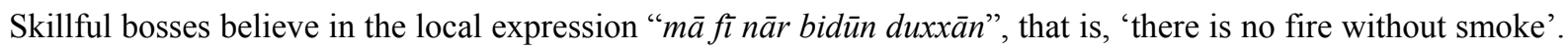
They are familiar with țaxtaxa, its reasons, and its objectives. They don't, in most cases, react or make a decision against the targeted person, unless the shooter provides critical evidence against his target. Inexperienced bosses, on the other hand, may not carefully examine the reasons and objectives of shooting and, thus, may take an action against the targeted person. However, when shooting takes place indoors with a skillful boss, there are four scenarios that represent the reaction of this boss. First, as shown in figure (5.A), an employee A is talking against his peer (B) to the boss. But the boss, as in figure (5.B), will be on touch with employee (B) to check all complaints against him as well as direct him. Eventually, as shown in (5.C), the boss does not make a decision against the targeted person (Note 4) except stopping communication with him, but maintains contact with the shooter to explore his reasons and objectives and, in certain cases, to use him as a source of information that 
provides a feedback about the work of other employees.
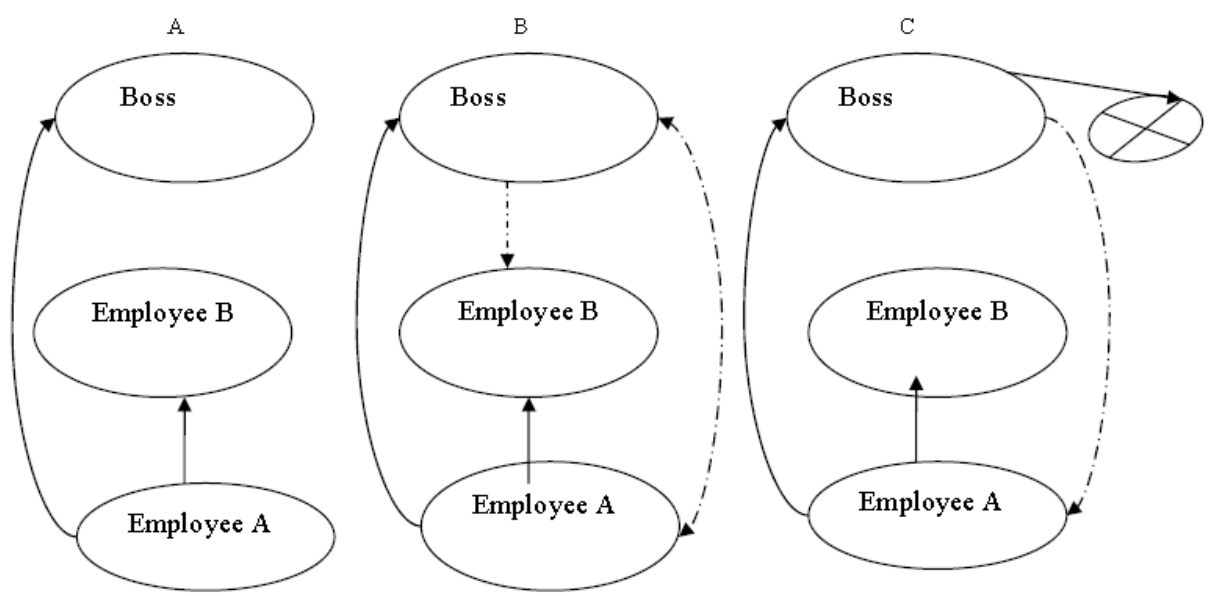

Figure 5. (A) An employee A is talking against his peer (B) to the boss. (B) The boss is on touch with employee (B) checking complaints and directing. (C) The boss stops contact with the targeted person and maintains it with the shooter.

Second, an employee is talking against his immediate boss to the higher boss as shown in figure (6.A). The higher boss, as in figure (6.B), will contact the concerned boss to question all complaints against him, while maintaining contact with the shooter to gather more details. The higher boss may not act against the target, as shown in (6.C), but will maintain listening to the shooter to get more feedback about the efficiency of the concerned boss for future evaluation or direction.
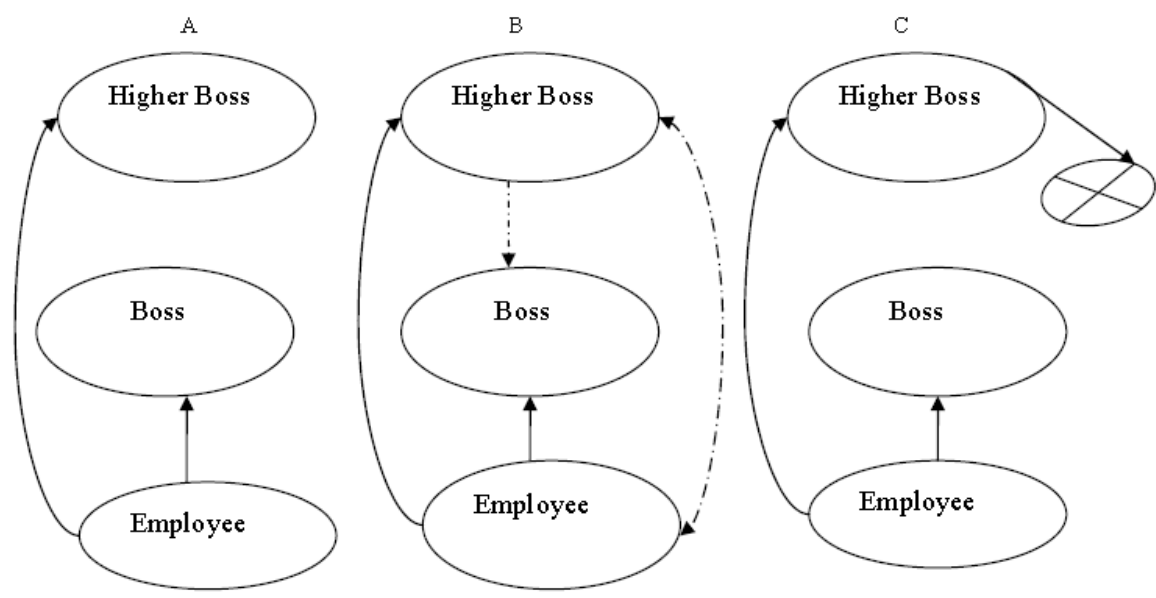

Figure 6. (A) An employee is talking against his immediate boss to the higher boss. (B) The higher boss contacts the concerned and maintains contact with the shooter. (C) The higher boss maintains listening to the shooter for future evaluation or direction.

Third, a boss may complain or argue against a competing person to a higher boss, as in (7.A). The higher boss, in turn, may maintain communication with both parties, as in (7.B). As a result, no action against the target may be taken. The higher boss may decide to discontinue communication with the shooter himself who fails to provide logical reasons against his target, as in (7.C). The shooter is a loser in this case, because the higher boss will maintain communication with his opponent. In other words, failure to practice strong shooting may change into a critical shooting against the shooter himself. 

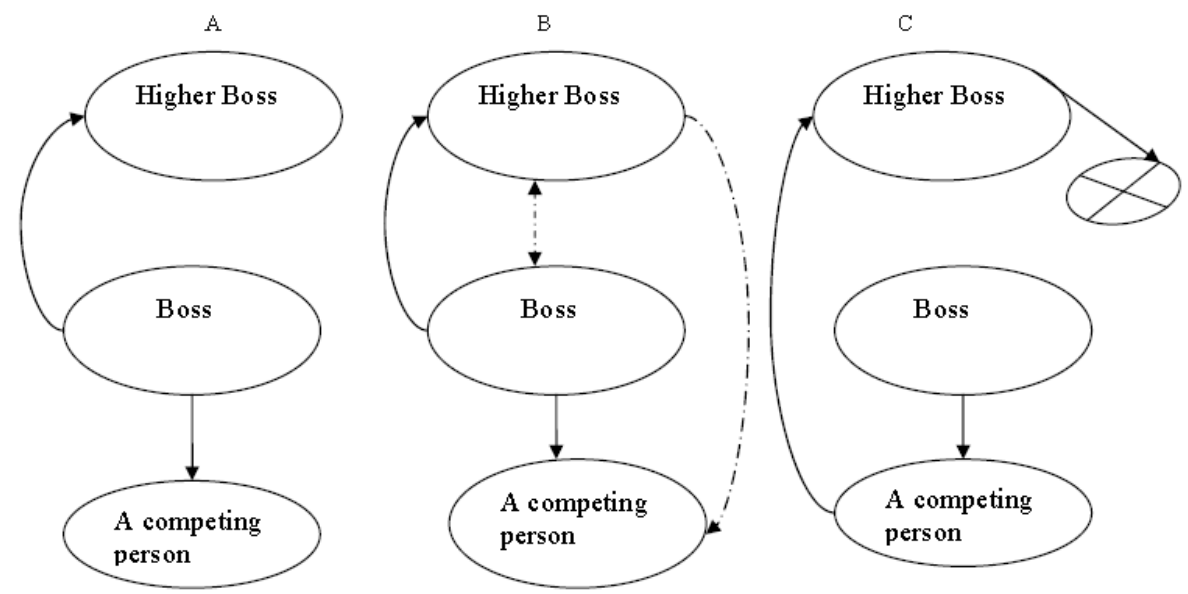

Figure 7. (A) A boss may complain or argue against a competing person to a higher boss. (B) The higher boss maintains communication with both parties. (C) The higher boss may decide to discontinue communication with the shooter.

Fourth, a boss may argue against an employee to a higher boss, as in (8.A). The higher boss, in turn, may maintain communication with this boss whose arguments might be convincing, as in (8.B). As a result, the higher boss may continue communication with the shooter to receive further information which will affect the status of the target and lead to making a decision against him.
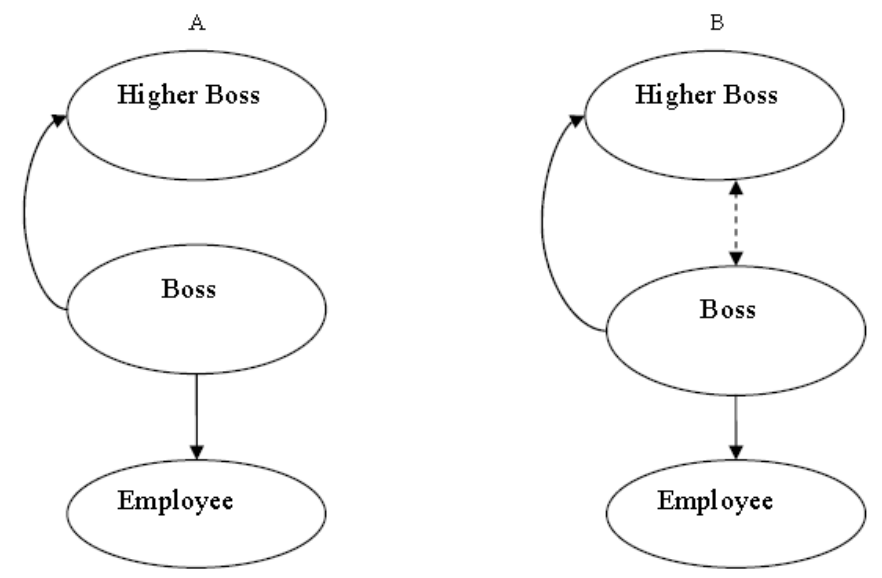

Figure 8. (A) A boss may argue against an employee to a higher boss. (B) The higher boss maintains communication with this boss.

Fifth, the same scenario mentioned above might be repeated but with a different shooter and a different target. Employee A may argue against employee B to their boss, as in (9.A). The boss may listen to the shooter whose arguments might be convincing, as in (9.B). Eventually, the boss may maintain contact with the shooter to receive further details which will affect the status of the target and lead to making a decision against him. 

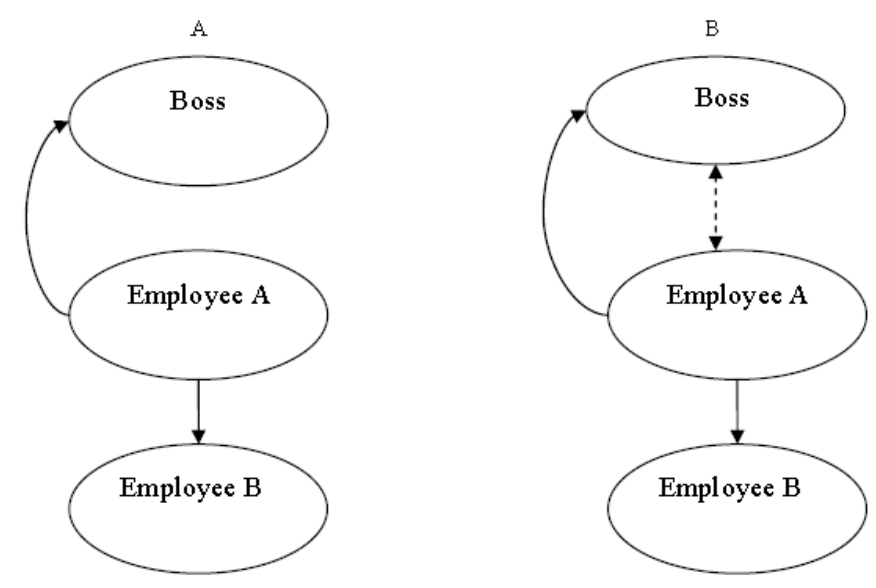

Figure 9. (A) Employee A may argue against employee B to their boss. (B) The boss may listen to the shooter whose arguments might be convincing.

\section{Effects of taxtaxa}

The question is does shooting affect the target. The answer is yes. This is evident from the following examples, where in (42) the shooter expresses his ability in achieving his aim through defeating his target:

(42) 'axadha bil 'azal 'I gave it (the shot) to him in the muscle'

fi așsamim '(he received the shot) in the heart'

țil 'at min rāșuh 'it (the shot) went out of his head'

To avoid consequences and as a protection measure, it becomes common among employees to warn each other by using labels that address a boss or certain peers who are skillful in practicing țaxtaxa routinely.

(43) fišu wilgabbir 'his shot sends to the grave'

lsānuh munšār 'his tongue is a saw

kalamuh yugtul 'his speech kills'

'abu alma'arik

'father of battles'

fiarbăğy

'a warrior'

\section{Conclusion}

The broad scenario of "a war of words" which represents "a conflict between languages or language and varieties" (Suleiman 2004; 15) is clearly evident when it is narrowed to an administrative setting, as it sheds light on a specific instance of such war. In this particular setting, which has its own linguistic aspects and components, an aggressive version of Arabic is used. This version triggers a battle of words which concerns a linguistic fight or struggle "between the speakers of a language who compete over resources and values in their milieus".

In an administrative setting, a battle of words can occur. In this battle, a skillful taxxīx 'shooter' or fiarbağy 'warrior'does his best to use the available weapons, which are words and expressions, to fight and defeat an opponent in "a conflict" triggered by a state of discord caused by the actual or perceived opposition of needs, values, and interests.

\section{Acknowledgments}

Thanks to all the anonymous reviewers of Asian Social Science for their constructive and useful comments and feedback. My sincerest appreciation also goes to all the administrative staff at Mu'tah University who were patient during the interviews and who kindly responded to the distributed questionnaire.

\section{References}

Bassiouney, R. (2009). Arabic Sociolinguistics. Edinburgh University Press. $\mathrm{http} / / / \mathrm{dx}$. doi.org/10.3366/edinburgh/9780748623730.001.0001

Boxer, D. (2002). Applying Sociolinguistics: Domains and Face-To-Face Interaction. Amsterdam: John Benjamins 
Coulmas, F. (1998). The Handbook of Sociolinguistics. Blackwell Handbooks in Linguistics. http://dx.doi.org/10.1111/b.9780631211938.1998.x

Coulmas, F. (2006). Sociolinguistics: The Study of Speakers' Choices. Cambridge: Cambridge University Press.

Downes, W. (2005). Language and society. Cambridge: Cambridge University Press.

Eadie, W. F., \& Nelson, P. E. (2000). The Language of Conflict and Resolution. Sage Publications, Inc.

Owens, J. (2001). Arabic Sociolinguistics. Arabica, 48, 421-469. http://dx.doi.org/10.1163/157005801323163816

Owens, J. (2006). A Linguistic History of Arabic. Oxford: Oxford University Press. http://dx.doi.org/10.1093/acprof:oso/9780199290826.001.0001

Romaine, S. (2000). Language in Society: An Introduction to Sociolinguistics. Oxford: Oxford University Press

Rouchdy, A. (Ed.). (2003). Language Contact and Language Conflict in Arabic: Variations on a Sociolinguistic Theme (Curzon Arabic Linguistics Series). London: Routledge-Curzon, Taylor \& Francis Group.

Searle, J. R. (2000). Mind, Language, and Society: Philosophy in the Real World. Basic Books.

Suleiman, Y. (1995). Arabic Sociolinguistics: Issues and Perspectives. Routledge.

Suleiman, Y. (2004). A War of Words: Language and Conflict in the Middle East (Cambridge Middle East Studies). Cambridge University Press. http://dx.doi.org/10.1017/CBO9780511819926

Thomas, L., Wareing, S., Singh, I., \& Peccei, J. S. (2003). Language, Society and Power: An Introduction. Routledge.

\section{Notes}

Note 1. The following symbols with their Arabic equivalents are used throughout this paper; ' $s, d, d, d \varphi$ $b$, d $y$ s

Note 2. This research was conducted during my sabbatical at Prince Mohamad Bin Fahad University at Al-Khobar, KSA, in the academic year 2007/2008. This study was inspired by a personal experience of taking over two different administrative positions at Mu'tah University, Jordan, for more than seven continuous years. This experience gave me the chance to interact with administrative staff at different administrative levels in different times and situations. To conduct this research, including data collection and analysis, interviews were made and a systematic questionnaire was distributed to more than 50 persons who were in different administrative positions at Mu'tah University. The questionnaire contained the following questions:

1) What do you think of taxtaxa?

2) Who are involved in it?

3) What are the types of it?

4) Do you practice țaxțaxa?

5) When do people practice it?

6) Why do other people practice it?

7) What are the advantages of it?

8) What are the disadvantages of it?

9) How do you react to it?

10) How do other people react to it?

11) What common expressions used to express it?

12) How do you defend yourself from it?

13) How do you defend others from it?

14) What are the reasons behind it?

15) What blocks it? 
Note 3. The following notions will be used for figure 1-9. Head of the curved non-dotted line means talking with or complaining to, head of the straight line means talking against, head of the curved dotted line means talking against, two heads means making a continuous contact, and a circle with a cross means no action is taken.

Note 4. This is represented by a crossed circle. 